\title{
70 éves a Geodézia és Kartográfia
}

\author{
Székely Domokos
}

DOI: https://doi.org/10.30921/GK.70.2018.3.2

\section{Bevezetés}

Ez évben a hetvenedik évfolyama jelenik meg a folyóiratunknak. A magyar geodéziai társadalom több mint másfél évszázados története során példátlan esemény, hogy szaklapunk ilyen hosszú idôn át, - sokszor válságos politikai és gazdasági körülmények között, - folyamatosan megjelenhetett. Az ország részletes felmérésének megindulása (1856) után szakembereink még nem rendelkeztek olyan periodikusan megjelenô lappal, amiben kifejthették volna munkáik során szerzett tapasztalataikat.

A 19. század közepén elindított Magyar Mérnök és Építész Egylet Közlönye, illetve a Vízügyi Értesítô néha helyet adott szakembereink (Kruspér István, Marek János, Halácsy Sándor és mások) cikkeinek. Ez azonban csepp volt a tengerben. Nagy lépést jelentett elốre, amikor 1892ben Dobrovics Viktor, majd Gánóczy Sándor gondozásában megjelenhetett a Kataszteri Közlöny; 1918 végéig rendszeresen tájékoztatta szaktársainkat az országos kataszteri felmérés helyzetérôl.

Az elsố világháborút követố rendkívül nehéz politikai és gazdasági helyzet miatt geodétatársadalmunk fórum nélkül maradt. Hatéves kényszerszünet után, Oltay Károly professzor kezdeményezésére, a Műegyetem, az Állami Földmérés és magánemberek támogatásával, 1925-ben elindult a Geodéziai Közlöny. 25 év után, az akkori politikai rendszer a lap további megjelenését nem engedélyezte. Hasonló sorsra jutott a HTI által szerkesztett, kiadott és 20 éven át gondozott Térképészeti Közlöny is. (A rövidítések magyarázata a cikk végén található.)

\section{0 év fóbb eseményei}

Folyóiratunk 70 éves történetét nem lehet néhány oldalon összefoglalni. 70 év alatt, 2017 végéig 428 szám jelent meg, közel 30000 oldal terjedelemben. (Egészen pontosan 29772 oldalon.) Eleinte évente 4 szám, majd 1962-től 6 szám, míg 1996-tól évente 12 szám jelent meg. 2011 óta ismét 6 szám jelenik meg. A Geodézia és Kartográfia (GK) kezdettôl fogva két fố részbool áll: szakcikkekbôl (főcikkekből) és szemlecikkekből. A szakcikkek száma 70 év alatt közel 3000 (becsült adat). Oldalterjedelmét tekintve ez a lap 70\%-át teszi ki, ami azt jelenti, hogy egy cikk átlagos hossza 6-7 oldal. Most nézzük az éves példányszám alakulását. Az 50-es évek elején (papírhiány miatt) számonként 600 példányban jelent meg. Ez a szám a 60-as évek elejére 1500-ra emelkedett, nem utolsó sorban a frissen alakult GKE-nek köszönhetôen, melynek már az 1956-os megalakulásakor 990 tagja volt. Ezután a példányszám fokozatosan csökkent: a 70-es években 1400-ra, a 80-as években 1300-ra, míg a rendszerváltozás után 1000-re mérséklődött. Lapunk ezt a példányszámot tartja napjaikban is.

Szólnom kell a lap külsố megjelenési formájáról. Az alapítástól 1996ig, azaz 47 éven át, A/4 formátumban, kezdetben változó oldalszámmal (40112 oldal), a hatvanas évektől kezdve 40+4 oldalon, fekete-fehér színben jelent meg. Ezután a szerkesztôség áttért a B/5-ös formátumra, színes borítóval, 48 oldalnyi terjedelemmel. 2011-tôl visszatértek az A/4 formátumra, kezdetben 32 oldalon, 2017 tôl 48 oldalon, és már a beltartalom is színes lett.

A lap kezdettől fogva megemlékezett az elhunyt kollégákról. Az 50-es években csak néhány sorban, amely a 60-as évekre egy hasábra is növekedhetett. A 70-es években már fényképpel is ellátták a megemlékezést, míg a 80-as években pedig kényesebb dolgokról (hadifogság, kitelepítés stb.) is lehetett írni. A rendszerváltás után már bátrabban lehetett írni az 56-os forradalom során elszenvedett hátratételekrôl (Virágh Dénes, Rubinka László, Szent-Iványi György és mások) az esetleges egyházi kötôdésekrôl (Kuti László, Bernhardt Mátyás ). Ritkán, de előfordult, hogy a leszármazottak nem járultak hozzá a nekrológ megjelenéséhez (Hunyady László, Annau Edgár). Mint az ismeretes, a nekrológok képezik az MFA-sorozat késóbbi köteteinek az alapját.

Ide kívánkozik néhány változás is, amin a lap a 70 éves története során átesett. Ilyen pl. a lap címe. 1949ben az ÁF a PM egyik fốosztálya volt. Ekkor a lap neve „Az Állami Földmérés Közleményei" volt. Mivel 1950-ben a fóosztály kivált a PM-ból, és OFI néven önálló szervezetté vált, a lap neve „Földméréstani Közlemények”-re változott. 1952-ben az OFI átalakult ÁFTH-vá, a lap neve - egészen 1955ig - nem változott. Ekkor tért át a szerkesztőség a "Geodézia és Kartográfia” elnevezésre, melyet a lap a mai napig megôrzött.

A 70 év alatt a lap szerkesztése többször változott. Kezdettől - mintegy hét éven át, - a lapot Regốczi Emil egyedül szerkesztette. Ez korábban a polgári világban, a folyóiratoknál nem volt ismeretlen (pl.: Gánóczy, Oltay stb.) Késôbb, 1956 után, szakemberekbôl szerkesztô bizottságot hoztak létre. 1962-tôl a szerkesztô bizottság ún. pozícióban lévố szakemberekkel (igazgatók, fômérnökök stb.) kibôvült. Különbséget kell azonban tegyünk a szerkesztôség tagjai (akik aktívan dolgoztak a lapnál) és a szerkesztô bizottság között. Ez utóbbi ritkán - és tegyük hozzá sokszor hiányosan - ülésezett, és gyakran szimbolikus jelentôséggel bírt.

1957 és 1990 között ún. „politikai kinevezettek" is szerepeltek a szerkesztőbizottságban. Elôször Antos Zoltán, aki az ÁFTH elnöke volt 10 évig. Az ô idôszakában tevékenykedett egy rövid ideig Kovács Márton mint Antos helyettese. 1967-tôl Halász Péter következett mint az OFTH hivatalvezetôje. Nyugállományba helyezése után ôt Matúz József követte. Matúz korai halála után a mezőgazdasági és élelmezésügyi -miniszter Hoffer Istvánt nevezte ki az OFTH élére. Ố ezt a feladatot és a szerkesztôbizottság elnöki tisztét a rendszerváltásig látta el. Ez 
után politikai kinevezett többet nem került be a szerkesztôbizottságba.

A GK 70 éves története során öt különszám is megjelent. Az elsô 1961ben Zelcsényi Géza disszertációját, a második 1963-ban több szakember tanulmányát tartalmazta. A harmadik (ünnepi) szám 1969-ben dr. Radó Sándor 70. születésnapjára készült. A negyediket Schmidt Edit állította össze 20 év (1949-1968) tartalomjegyzékeibôl. Ennek készítette el Vörös Imre a folytatását (1969-1978), mely már nem különszám formájában, hanem a GK 1979. 3-6 és 1980. 1 számaiban jelent meg. (Itt jegyzem meg, hogy milyen kár, hogy ennek a kiváló kezdeményezésnek napjainkig nincs folytatása, pedig a kutatómunkát jelentôsen megkönynyítené.) 2009-ben a GK 60. születésnapjára jelent meg az ötödik, jubileumi különszám, amely az elmúlt 60 év szakmai részterületeinknek a GK folyóiratban bemutatott eredményeit foglalta össze.

Szólnom kell az olvasószerkesztőkrôl. Ezt a munkát 30 éven át dr. Regốczi Emil maga végezte el. 1980-tól 2000-ig Vörös Imre látta el ezt a feladatot. Utóda - 2005-ben bekövetkezett korai haláláig - Apagyi Géza volt. 2008 és 2012 között Hodobay-Böröcz András vette át az olvasószerkesztôi feladatokat. Végül 2013tól Kota Ágnes, a lap impresszumában csak 2014-tôl szerepel mint olvasószerkesztô. A lap technikai szerkesztôje napjainkban: Szrogh Gabriella.

Természetesen 70 év igen hosszú idô ahhoz, hogy egyetlen kiadó, ill. egyetlen nyomda lássa el a sokszorosítást és a terjesztést. Az 50-es években a Tervgazdasági Kiadó és az Egyetemi Nyomda végezte ezt a munkát. 19601990 között a lapot a KV adta ki. Előbb a Révay Nyomda, késôbb az Egri Nyomda végezte a sokszorosítást. A rendszerváltás után a Cartográfia Kft. lett a kiadó és a Békéscsabai Nyomda a sokszorosító. Késôbb az MFTTT lett a kiadó, és a katonai térképészet nyomdája (különbözô szervezeti megnevezésekkel, napjainkban HM Zrínyi Térképészeti és Kommunikációs Szolgáltató Közhasznú Nonprofit Kft. néven) végzi a sokszorosítást.

A GK szerkesztôsége 1949 és 2006 között, minden évben elkészítette az éves, egyesített tartalomjegyzéket.
Sajnálatos módon, 2007-óta éves tartalomjegyzék nem készül. Történt ugyan néhány éve kísérlet a pótlására az interneten, de ezek az adatok (tekintve hogy virtuálisak) nem idôtállók, és a közkönyvtárak nem tárolják.

Szaklapunk szerkesztését 70 év alatt hat főszerkesztô irányította. 1949 és 1980 között dr. Regốczi Emil töltötte be ezt a tisztet. Halála után ôt (19801990 között) Jagasics Béla követte. A rendszerváltáskor Vörös Imre lett a lap fôszerkesztôje egészen 1995-ig, majd 2000-ig mint szerkesztô dolgozott a lapnál. 1995-ben dr. Joó Istvánt nevezték ki fôszerkesztônek, aki ezt a tisztet 2007-ben bekövetkezett váratlan haláláig látta el. Ezután fél év szünet következett, mely idő alatt, átmenetileg dr. Mihály Szabolcs a FÖMI fóigazgatója és Horváth Gábor a FVM fóosztályvezetôje közösen látta el a lap szerkesztését. 2008. januárban - a két tulajdonos közötti kompromisszum alapján, dr. Riegler Pétert nevezték ki főszerkesztőnek, aki ezt a tisztet 2016 év végi viszszavonulásáig látta el. Utóda 2017. januártól Buga László mérnök ezredes.

\section{Néhány szó 70 év \\ fószerkesztôiroól}

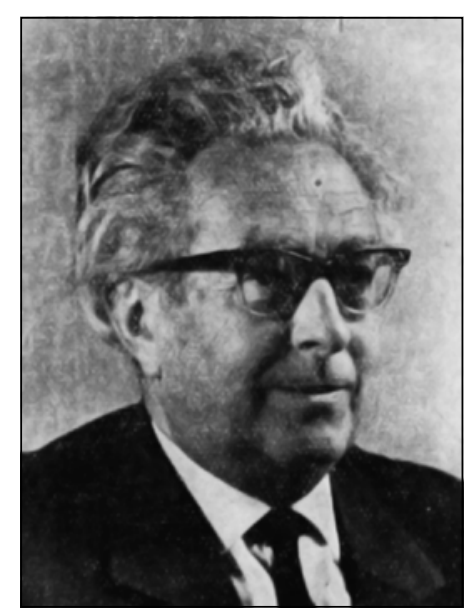

Prof. dr. Regốczi Emil

1900-ban született Székesfehérváron. Mérnöki oklevelét a Múegyetemen 1924-ben szerezte meg. 1925-ben lépett az ÁF szolgálatába, és 1928-tól már a HH fốmérnöke. 1944-tôl a PM múszaki tanácsosa. 1945-1947 között szovjet hadifogságban volt. („málenkij robot") 1948-tól ismét a PM-ben dolgozott. 1950-tôl az OFI múszaki fôtanácsosa. 1952-tôl a GKI igazgatója. 1953-ban Kossuth-díjat kapott. A Lázár deák emlékérem és a Fasching Antal-díj kitüntetettje. 1960-ban történt nyugalomba vonulása után, 20 éven át (1980ban bekövetkezett haláláig) már csak a GK szerkesztésével foglalkozott.

Munkássága alatt, - hiszen ő volt a lap megalapítója és szellemi atyja, alakult ki a lap arculata, mely 47 éven át (1995-ig) változatlan maradt. Prof. dr. Homoródi Lajos cikkében, a következô szavakkal méltatta Regôczi fôszerkesztői munkásságát: „,... nemcsak szakmai szempontból ellenőrzi és javítja a beérkezô cikkeket, hogy lapunk a nemzetközi szakirodalomban is elismert színvonala töretlen legyen, hanem fáradhatatlanul csinosítja is a cikkek stílusát, nyesegeti magyartalanságukat, irtja a pongyolaságot, és tanít világosan, tömören fogalmazni." (Homoródi 1979) Prof. dr. Joó István így búcsúzott Regôczitôl a temetésén: „...Egyszerre voltál nekünk példa, tanítás, útbaigazítás és igaz, hú barát. Példát adtál, hogy kell szeretni a munkát és vele az életet. Miképpen kell tisztelni az embert és vigyázni a becsületre. [...] Arcod, egyéniséged vonásait megốrizzük." (Joó 1980)

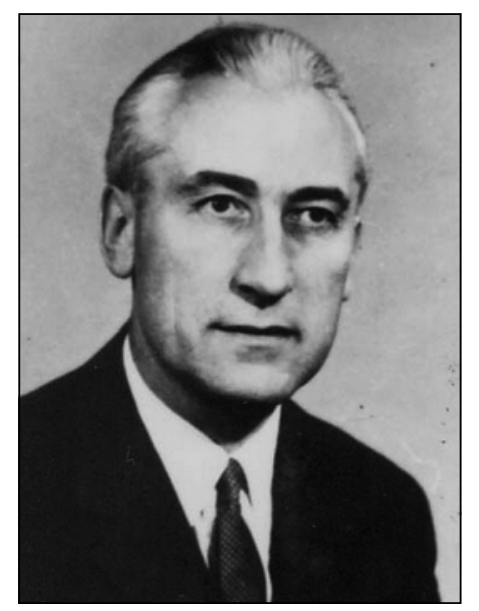

Jagasics Béla

1920-ban született Nemesapátiban. A Soproni Egyetemen 1958-ban szerzett diplomát. 1959-tôl 1969-ig a Vas Megyei Földhivatalnál különbözô beosztásokban dolgozott. 1970-ben kinevezték a FÖMI igazgatójának, ahonnan 1981ben nyugállományba vonult. 1990-ig volt a GK főszerkesztôje. Munkája elismeréséül megkapta a Fasching Antaldíjat, a Térképészet Kiváló Dolgozója, és a Munka Érdemrend ezüst fokozata kitüntetéseket. 2007-ben hunyt el. 
80. születésnapja alkalmával dr. Joó István laudációjában a következôket írta: „...pályájára pillantva a 80 esztendôs életkor nem tûnik éppen csekély dolognak, hiszen mögötte sokrétú, felelősséggel járó, és sok évtizedes, eredményes tevékenység rejlik. [...] kemény munkával küzdötte fel magát, megtartotta otthonról hozott felelôsségtudatát, a munka tiszteletét és szeretetét, a mindig jobbítani akarás szándékát, és szerény magatartását." (Joó 2000).

Temetésén Winkler Péter és Busics György a következố szavakkal búcsúztatta Jagasics Bélát: „,..érzékeny, nemes szív lakozott benned. Segítettél, ahol és akinek csak tudtál. [...] Mint a lap főszerkesztôje, aprólékos gonddal, precíz munkával készítetted elő a nyomdai leadásra szánt cikkeket. [...] Teljes életet éltél, pályádat befutottad, kötelességedet teljesítetted, optimizmusodat és hitedet megtartottad." (GK 2007).

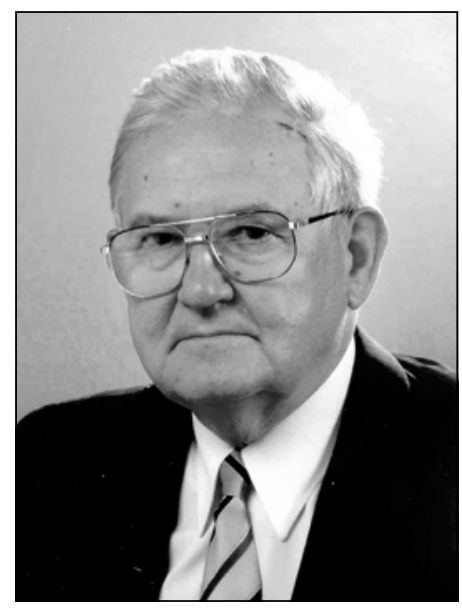

Vörös Imre

1933-ban született Hódmezóvásárhelyen. Diplomáját 1963-ban, levelezó úton, a Múegyetemen szerezte. 1958-tól 10 évig a BGTV-nél különbözô beosztásokban dolgozott. 1969-ben a FÖMI Tudományos Kutatási Fôosztályára került, ahol 10 évig a Geodinformot szerkesztette. 1980-tól a GK szerkesztôje, majd 1990tôl - öt éven át - fôszerkesztôje volt. 1993-ban Fasching Antal-díjat kapott. 2000-ig még szerkesztője volt a lapnak, majd nyugállományba vonult.

Vörös Imre a GK-nál eltöltött 20 év alatt rendkívüli alapossággal és precizitással gondozta a lapot. Szinte mindenes volt: olvasószerkesztő, fordító, lektor, technikai szerkesztô. Nemcsak a cikkírókkal, de a nyomdákkal is állandó, szoros kapcsolatot tartott. Felsőfokú olasz és angol nyelvtudással rendelkezett, így aki cikkéhez idegen nyelvú rezümét nem tudott csatolni annak ô ezt megírta. Szorgalma, munkabírása és szerénysége példamutató a következố generációk számára.

80. születésnapja alkalmával, dr. Mihály Szabolcs és Zsámboki Sándor közös laudációjukban a következôket írták: „...A Társaság életében különös jelentôsége és fontossága van a GK-nak, mely lehetôséget ad szakterületünket érintố publikációk megjelenésére. [...] Hogy ez így valósuljon meg, elkötelezett, szakmailag jól felkészült szerkesztőre van szükség. Vörös Imre kollégánk, 20 éven keresztül ilyen volt. [...] 80. születésnapján, - Társaságunk és az olvasók nevében, - szeretettel köszöntjük." fejeződik be az interjú. (Zsámboki-Mihály 2013)

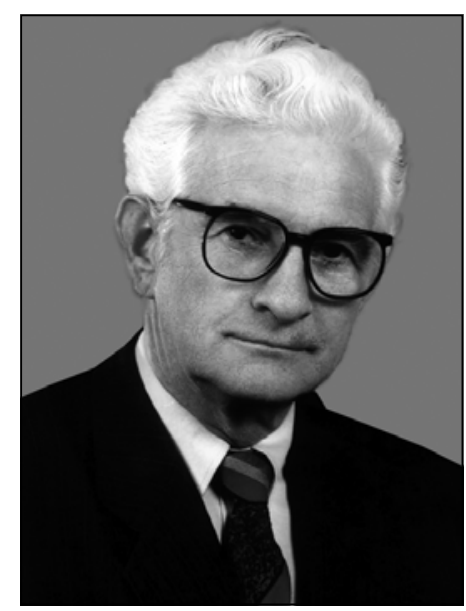

Prof. dr. Joó István

1928-ban született Hidashollóson. Oklevelét a BME hadmérnöki karán, 1954-ben szerezte meg. A HTI-ben, majd az FTV-ben, később a KV-nál végzett szakszolgálatai után, 1961ben az ÁFTH-hoz került, ahol 1962tôl - 25 éven át - a Mûszaki Fôosztályt vezette

1964-ben doktorált, 1968-ban a kandidátusi, majd 1979-ben a akadémiai doktori fokozatot szerezte meg. Publikációinak száma több mint háromszáz. Kiváló munkáját sok kitüntetéssel jutalmazták, közöttük a Lázár deák emlékéremmel és a Fasching Antal-díjjal, illetve a Munka Érdemrend valamennyi fokozatával. 1986-ban kinevezték a Soproni Egyetem professzorának. Korábban felelôs szerkesztôje, majd 1995-tôl haláláig fôszerkesztốje volt a GK-nak. 2007-ben hunyt el.

Joó István negyedszázadon át állt az ÁF élén. Ezalatt az idô alatt nevéhez fúzôdik, - többek között - az EOV és az EOTR bevezetése, az egységes földnyilvántartási rendszer kialakítása, a FÖMI és a Penci Obszervatórium felállítása, a székesfehérvári Földmérési és Földrendezôi Fốiskolai Kar létrehozása, a távérzékelés hazai intézményesítése, modern fotogrammetriai és geodéziai eszközök beszerzése stb., stb. Szinte lehetetlen felsorolni mennyi mindent tett 50 éves szolgálata során a magyar geodéziai társadalomért.

75. születésnapja alkalmával Apagyi Géza és dr. Márkus Béla laudációjukban ezekkel a szavakkal köszöntötték: „....Eredményes szakmai és tudományos tevékenységéért, közel ötven éves alkotó munkásságáért, a Soproni Egyetem professor emeritus címmel jutalmazta. [...] A magyar geodéta társadalom nevében köszöntjük, és további sikereket, jó egészséget kívánunk dr. Joó István professzor úrnak." (ApagyiMárkus 2003)

Ezután is rengeteget dolgozott. Szervezete nem bírta már a megterhelést, és 2007. augusztus 5-én eltávozott az élók sorából. Temetése alkalmával lapunk szerkesztôbizottsága a következô szavakkal búcsúzott fôszerkesztôjétôl: „...Elhunytával a magyar földmérôk és térképészek nagy megbecsüléssel emlékeznek rá." (MárkusMihály 2007).

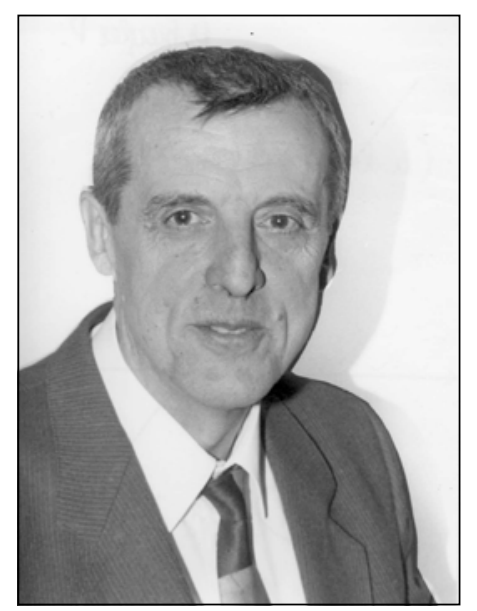

Dr. Riegler Péter

1940-ben született Szekszárdon. 1965-ben szerezte meg oklevelét az ÉKME-en. Ezután a PGTV-nél helyezkedett el. A ranglétra minden fokát 
végigjárta. Volt beosztott mérnök, csoportvezetô, kirendeltségvezetô, osztályvezetô, fôosztályvezetô, igazgató helyettes (főmérnök) és végül, 1985tôl kinevezték a PGTV igazgatójának. Doktori tudományos fokozatát 1976ban szerezte meg. A Lázár deák emlékérem és a Fasching Antal-díj kitüntetettje, c. fóiskolai tanár. 1993-ban a Baranya Megyei Földhivatal vezetésével bízták meg. 1996-ban, átmenetileg, mint kormánybiztos koordinálta az NKP munkáját. Ezután visszatért a Földhivatal élére, ahonnan 2005-ben nyugállományba vonult. Dr. Joó István váratlan halálát követôen, 2008-ban kinevezték a GK fôszerkesztôjének. Ezt a beosztást 2016 végéig látta el.

Főszerkesztôi bevezetôjében Riegler Péter a következőket írta: „...A szerkesztôi munka hatékonyabbá tétele érdekében - a korábbi gyakorlattól eltérôen - egy kis létszámú szerkesztőséget kívánunk létrehozni. [...] Szeretnénk emellett, ha a lap szerkesztését a Szerkesztôbizottság továbbra is segítené. [...] Befejezésül köszönetet szeretnénk mondani a laptulajdonosoknak, az MFTTT elnökének és az IB-nek a lap szakmai és anyagi támogatásáért.” (Riegler 2008)

70. születésnapja alkalmával, dr. Mihály Szabolcs laudációjában a következóket írta: „...több évtizedes, lelkiismeretes munkája mellett emberi magatartása, közvetlen modora és kapcsolatépítô képessége nagy elismerést érdemel. Az MFTTT tagsága nevében is további eredményes munkát, sok sikert és jó egészséget kívánunk!" (Mihály 2010)

Dr. Ádám József MFTTTelnök és Horváth Gábor István FM-főosztályvezetô az Eredmények és feladatok c. évértékelôjükben a következóket írták: ,...Kilencévi eredményes munkálkodás után dr. Riegler Péter, Társaságunk örökös tagja szaklapunk fôszerkesztôi tisztségétôl megvált. A tulajdonosi jogokat gyakorló MFTTT és FM, 2017. január elsejével Buga László helyettes fôszerkesztôt megbízza a fôszerkesztối teendốk ellátásával." (Buga 2017)

\section{Buga László}

1954-ben született Pásztón. Mérnöki oklevelét, 1978-ban Moszkvában

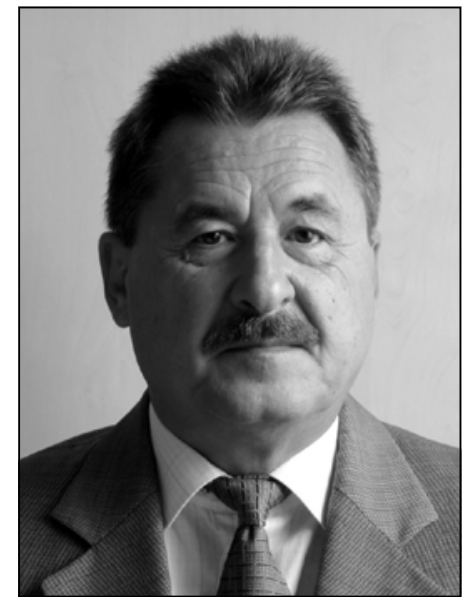

szerezte meg. 1978-tól a MN Térképészeti Intézetben helyezkedett el, ahol különböző beosztásokban - 1979-tôl mint hivatásos katona - dolgozott. 2001-tốl 2010-ig az Intézet szakmai jogutódjaként múködô HM Térképészeti Kht. ügyvezetô igazgatója volt. Fasching-díjban részesült, majd Lázár deák emlékéremmel tüntették ki. 1996-óta tagja a GK szerkesztôbizottságának. 1994 és 2003 között, illetve 2013-tól az MFTTT IB tagja, illetve fótitkárhelyettes. 2009-tôl c. egyetemi docens az ELTE-n. 2013tól rendelkezési állományú mérnök ezredes. 2013-óta a GK fôszerkesztôhelyettese, majd 2017. január 1-jétől a lap főszerkesztôje.

Dr. Mihály Szabolcs, az MFTTT elnöke, a Lázár deák emlékérem átnyújtásakor, Buga László életútját a következő szavakkal méltatta: „...széles körú elméleti ismeretekkel, több évtizedes szakmai és vezetôi gyakorlattal rendelkezik. [...] Kiemelkedô szerepe van a katonai és polgári térképészeti szolgálatok közötti együttmúködés megszervezésében és végrehajtásában." (Mihály 2011)

Buga László - lapunk hasábjain főszerkesztôi tevékenységének célkeresztjébe a következóket helyezte: „Változtatni kívánunk a korábbi lapszámok online elérhetôségén is ${ }^{1}$. A meg-

\footnotetext{
1 2017-ben sikerült újra aktív státuszba helyezni a lapot a Scopusban, a világ egyik legrangosabb, tudományos lektorált folyóiratok absztrakt és hivatkozás nyilvántartó adatbázisában. Az ELTE Egyetemi Könyvtárral kötött együttmúködési megállapodásunknak köszönhetôen 2018-tól bevezettük a főcikkek DOI (Digital Object Identifier) azonosítását. Az azonosító alkalmazásával a Crossref metaadat rendszer felhasználói lettünk, amelynek a feladata a DOI nyilvántartatása. A DOI segítségével a cikkek hivatkozása könnyebb és egyértelmúbb, valamint előse-
}

jelenô - valamint a korábbi - számok tartalomjegyzékei [...] pár évre visszamenôleg, Társaságunk Honlapján már most is elérhetôek. Az ELTE támogatásával rövidesen honlapunkon megjelenik az a keresô felület, [...] amely emelni fogja lapunk publikációs értékét." (Buga 2017)

\section{Összefoglalás}

Már cikkem elején is megjegyeztem, hogy a GK 70 éves történetérôl köteteket lehetne írni. Ez a cikk csak pillanatkép az elmúlt évtizedekrôl.

Megemlékezésem két részből áll. Az elsố részben foglalkozom a lap - két emberöltốt átívelố - fôbb eseményeivel. Ezalatt az idố alatt szakterületünket sokszor átszervezték. Hogy a GK még egyáltalán létezik, az a szakmában dolgozók szeretetének, az elôállítók töretlen hitének és az olvasók húségének köszönhetô.

Megemlékezésem második részében igyekeztem bemutatni a fôszerkesztôket, akik ennek az embert próbáló kitartásnak élharcosai voltak, illetve ma is azok. Fáradozásuk - mint az tapasztalható - nem volt hiábavaló. Lapunk születésnapján kívánom, hogy a GK még sokáig bizonyítsa itthon és külföldön egyaránt: van még magyar Geodézia és Kartográfia!

\section{Alkalmazott rövidítések}

ÁF = Állami Földmérés; ÁFTH = Állami Földmérési és Térképészeti Hivatal; BGTV = Budapesti Geodéziai és Térképészeti Vállalat (most: Geodézia Zrt.); BME = Budapesti Múszaki és Gazdaságtudományi Egyetem; ÉKME = Építôipari és Közlekedési Múszaki Egyetem; ELTE = Eötvös Loránd Tudományegyetem; EOV = Egységes Országos Vetületi Rendszer; EOTR = Egységes Országos Térképrendszer; FÖMI = Földmérési és Távérzékelési Intézet (korábban Földmérési Intézet) FTV = Földmérô és Talajvizsgáló Vállalat; FVM FTF = Földmúvelésügyi és Vidékfejlesztési Minisztérium Földügyi és Térképészeti Fôosztály. (Az elnevezés idôközönként változott, most: FM FTF); GK = Geodézia és Kartográfia;

gíti a hivatkozások pontos nyomon követését, számszerúsítését. (Szerkesztôség) 
GKI = Geodéziai és Kartográfiai Intézet; $\mathrm{HH}$ = Háromszögelő Hivatal; HTI = Honvéd Térképészeti Intézet (Az elnevezés többször változott, most HM Zrínyi Térképészeti és Kommunikációs Szolgáltató Közhasznú Kft..); IB = Intézőbizottság; $\mathrm{KV}=$ Kartográfiai Vállalat (késóbb: Cartographia Kft.); MFA = Magyar Földmérôk Arcképcsarnoka; MFTTT = Magyar Földmérési, Térképészeti és Távérzékelési Társaság; NKP = Nemzeti Kataszteri Program Kht.; OFI = Országos Földméréstani Intézet; MÉM OFTH = Mezôgazdasági és Élelmezésügyi MinisztériumOrszágos Földügyi és Térképészeti Hivatal; PM = Pénzügyminisztérium; PGTV = Pécsi Geodéziai és Térképészeti Vállalat

\section{Irodalom}

Apagyi Géza - Márkus Béla: Joó lstván 75 éves. Geodézai és Kartográfia 2003. 11. sz.

Apagyi Géza: 10 éves a megújult Geodézia és Kartográfia. 2005. 10. sz.

Buga László: Geodézia és Kartográfia 2016. Geodézia és Kartográfia 2017. 1. sz.

Homoródi Lajos: 25 éves a Geodézia és Kartográfia. 1973. 6. sz.

Joó István: Búcsú Regốczi Emiltôl. Geodézia és Kartográfia 1980. 2. sz.

Joó István: Elôszó. Geodézia és Kartográfia 1995. 5. sz.

Joó István: Szaklapunk a Geodézia és Kartográfia Emlékkönyv, 2006.

Joó István: Születésnapi beszélgetés Jagasics Bélával. Geodézia és Kartográfia 2000. 9. sz.

Márkus Béla - Mihály Szabolcs: Búcsú Joó Istvántól. Geodézia és Kartográfia 2007. 8. sz.

Mihály Szabolcs: Buga László a Lázár deák emlékérem kitüntetettje. Geodézia és Kartográfia 2011. 7. sz.
Mihály Szabolcs: Riegler Péter 70 éves. Geodézia és Kartográfia 2010. 7. sz.

Riegler Péter: (szerk.) 60 éves a Geodézia és Kartográfia Jubileumi szám, 2009

Riegler Péter: Fôszerkesztôi bevezetô Geodézia és Kartográfia. 2008. 1-2. sz.

Székely András - Füri Klára: Beszélgetés Dr Regốczi Emillel. Geodézia és Kartográfia 1975. 2. sz.

Winkler Péter: Búcsú Jagasics Bélától Geodézia és Kartográfia 2007. 6. sz.

Zsámboki Sándor - Mihály Szabolcs: Vörös Imre lapunk nyugdíjas szerkesztôje 80 éves. Geodézia és Kartográfia 2013. 11-12. sz.

\section{Summary}

The issues of the seventieth volume of Geodézia és Kartográfia, the professional journal of Hungarian surveyors and cartographers come out in this year. The journal has been published with this name since 1955 The earlier volumes appeared under the names, Állami Földmérés Közleményei (Review of the National Survey) and Földméréstani Közlemények (Geodetic Review). Up to end 2017, about 3,000 publications appeared in the journal on almost 30,000 pages of 428 issues. Scientific papers amount to some $70 \%$ of the full extent. Besides, the issues also published news on professional events. The present paper gives a short review on the changes of the editorial principles and practices, commemorates the colleagues who helped the work of the editors, and remembers the major events of the time of almost two generations. In the second half of the paper, the author presents the editor-in-chiefs of the journal. This position was held first by Dr. Emil Regóczi (between 1949 and 1980) followed by Béla Jagasics (1980-1990). After the political transformation of Hungary, Imre Vörös was the editor-in-chief until 1995; then, Dr. István Joó was appointed, who held the position until his sudden death in 2007. After this, provisionally for half a year, the journal was managed jointly by Dr. Szabolcs Mihály, director of the Institute of Geodesy, Cartography and Remote Sensing, and Gábor Horváth, head of department in the Ministry of Agriculture and Rural Development. As of January 2008, Dr. Péter Riegler became the editor-in-chief, who held the position until his retirement at end 2016. His successor is László Buga, engineer colonel, since January 2017.

Kulcsszavak: Geodézia és Kartográfia, magyar geodéziai és térképészeti szakfolyóirat, 70 éves történet

Keywords: Geodézia és Kartográfia, Hungarian professional journal of geodesy and cartography, 70 years history

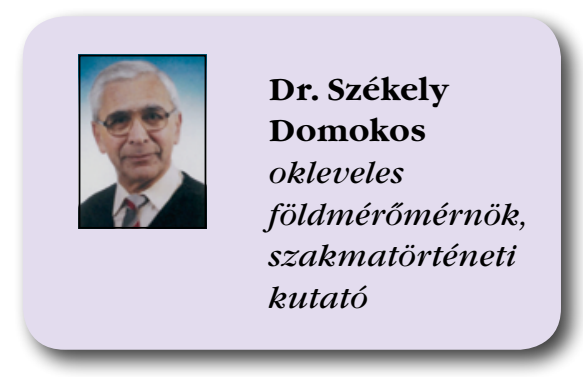

